\title{
Heating Rate and Liquid Glass Content Influence on Cement Brick Dehydration
}

\author{
V. Strokova ${ }^{(\bowtie)}$ and D. Bondarenko \\ Department of Material Science and Material Technology, Belgorod State \\ Technological University named after V.G. Shukhov, Belgorod, Russia \\ vvstrokova@gmail.com
}

\begin{abstract}
Peculiarities of Portland cement dehydration in different hydrate phases with sodium water glass have been given. Three endoeffects were determined during non-isothermal heating, connected with ettringite dehydration and water extraction at temperature ranges $98.7-110.0{ }^{\circ} \mathrm{C}$, calcium hydroxide decomposition at temperature ranges $439.4-450.7{ }^{\circ} \mathrm{C}$ and secondary carbonates decomposition at temperature ranges $657.4-669.3{ }^{\circ} \mathrm{C}$. We experimentally proved that the rates of dehydration of hydrated Portland cement was significantly influenced by the liquid glass concentration. Optimum liquid glass content was grounded in the protective layer of composite finishing material, modified with low-temperature plasma.
\end{abstract}

Keywords: Plasma-chemical modification - Dehydration - Cement brick · Soda water glass

\section{Introduction}

Plasma-chemical modification is one of the promising technologies of creating protective-decorative coatings in the manufacture of finishing construction materials for building and construction faces (Bondarenko et al. 2018a, b; Bessmertny et al. 2018; Bondarenko et al. 2016; Volokitin et al. 2016). Dehydration, melt formation and accumulation during plasma melting take second fractions, and the surface is heated up to $2000{ }^{\circ} \mathrm{C}$. As a result of high temperature impact hydro silicate dehydration in the surface layers can result in micro cracking and protective-decorative coating softening, as well as coating adhesion strength reduction and lowering of cold resisting properties.

Insufficient technology elaboration on reducing heat impact consequences and dehydration minimizing plasma melting of cement concrete does not allow wide application of these materials on the national market. That is why the main task in developing treatment technologies for materials based on cement matrix is composition development for protective coating which eliminate these processes. 


\section{Methods and Approaches}

To prove the efficiency of Portland cement and liquid glass application in the protective coating during manufacture of composite finishing material with plasma surface treatment the samples were prepared at waterlconcrete ratio 0.3 from pure Portland cement (CEM I 42,5 H) and with 5 and $10 \%$ of soda water glass $\left(\rho=1,4 \mathrm{~g} / \mathrm{sm}^{3}\right.$, silica modulus 2.8) of water of mixing. After hardening at normal conditions during 28 days, the samples were exposed to differential-thermal analysis.

Plasma-chemical surface modification is done in non-isothermal conditions at heating rate $3000{ }^{\circ} \mathrm{C} / \mathrm{min}$. It makes impossible to study dehydration in real conditions of plasma heating. This process was simulated with simultaneous thermal analysis device Netzsch STA $449 \mathrm{~F} 3$ Jupiter at heating rates $5{ }^{\circ} \mathrm{C} / \mathrm{min}$ and $10^{\circ} \mathrm{C} / \mathrm{min}$ with maximum heating rate $1000{ }^{\circ} \mathrm{C}$.

\section{Results and Discussion}

The thermograph of pure hydrated Portland cement shows three endoeffects (Table 1). The first endoeffects, in the temperature range $98.7-110.0{ }^{\circ} \mathrm{C}$ in the low temperature area, is connected with ettringite dehydration $\left(\mathrm{Ca}_{6} \mathrm{Al}_{2}\left(\mathrm{SO}_{4}\right)_{3}(\mathrm{OH})_{12} \cdot 26 \mathrm{H}_{2} \mathrm{O}\right)$ and water extraction. Endoeffects of these two processes superimpose each other. The second is connected with calcium hydroxide dehydration $\left(\mathrm{Ca}(\mathrm{OH})_{2}\right)$ and happens at temperature ranges $439.4-450.7{ }^{\circ} \mathrm{C}$. The third endoeffects $\left(657.4-669.3{ }^{\circ} \mathrm{C}\right)$ is connected with the secondary hydro carbonates dehydration $\left(\mathrm{CaCO}_{3}\right)$. Complete water extraction is at $900{ }^{\circ} \mathrm{C}$.

Table 1. Changing of endoeffects with the introduction of liquid glass and heating range 5 and $10{ }^{\circ} \mathrm{C} / \mathrm{min}$

\begin{tabular}{l|l|l|l|l|l|l|l}
\hline Endoeffect producer & $\begin{array}{l}\text { Pure } \\
\text { hydrated } \\
\text { Portland } \\
\text { cement }\end{array}$ & $\begin{array}{l}\text { Portland } \\
\text { cement with } \\
5 \% \text { liquid } \\
\text { glass }\end{array}$ & $\begin{array}{l}\text { Portland } \\
\text { cement with } \\
10 \% \text { liquid } \\
\text { glass }\end{array}$ \\
\hline & \multicolumn{4}{|l|}{ Heating range, ${ }^{\circ}$ C/min } & & \\
\cline { 2 - 8 } & 5 & 10 & 5 & 10 & 5 & 10 \\
\hline Ettringite and physically-coupled water & 98.7 & 110.0 & 92.6 & 106.4 & 92.8 & 108.0 \\
\hline Calcium hydroxide & 439.4 & 450.7 & 437.8 & 450.6 & 438.0 & 452.6 \\
\hline Secondary carbonate and hydro silicate & 657.4 & 669.3 & 662.0 & 683.1 & 663.0 & 693.6 \\
\hline
\end{tabular}

Similar results were received with the hydrated Portland cement after adding 5 and $10 \%$ liquid glass (Table 1).

A positive effect of liquid glass adding on secondary carbonate and hydro silicate endoeffects, which are responsible for cement brick softening and micro cracking at higher temperature range, can be explained by effect of encapsulation of hydrate phases with coating of liquid glass. 
Adding sodium silicate solute into Portland cement in the amount 5 and $10 \%$ takes down mass loss (TG) in ettringite dehydration area (Fig. 1). But in high temperature area dehydration intensity increases up to $2-3 \%$, it is especially notable with $10 \%$ liquid glass.

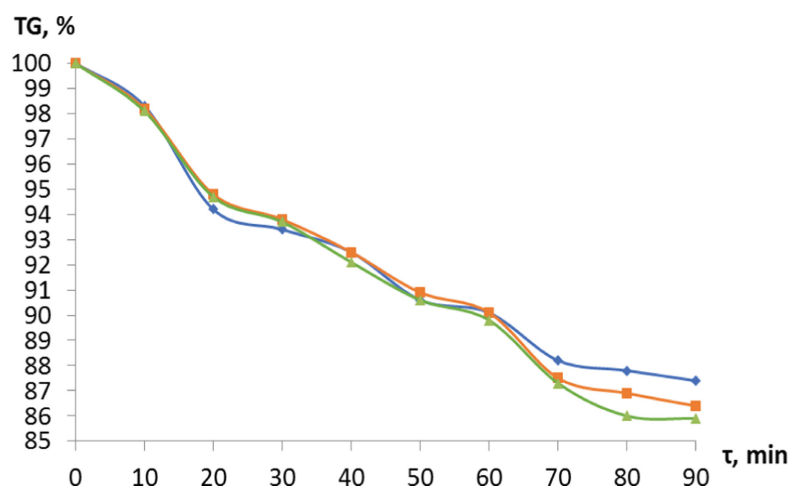

Fig. 1. Dependence of water loss on time at heating range $10{ }^{\circ} \mathrm{C} / \mathrm{min}$ : — Portland cement; Portland cement with 5\% liquid glass; _ Portland cement with $10 \%$ liquid glass

The highest dehydration rate is in low temperature area (Fig. 2), which is caused by ettringite dehydration (first climax). The second and third climaxes are connected with dehydration of calcium hydroxide, secondary carbonate and different hydro silicates, are below the first climax by magnitude.

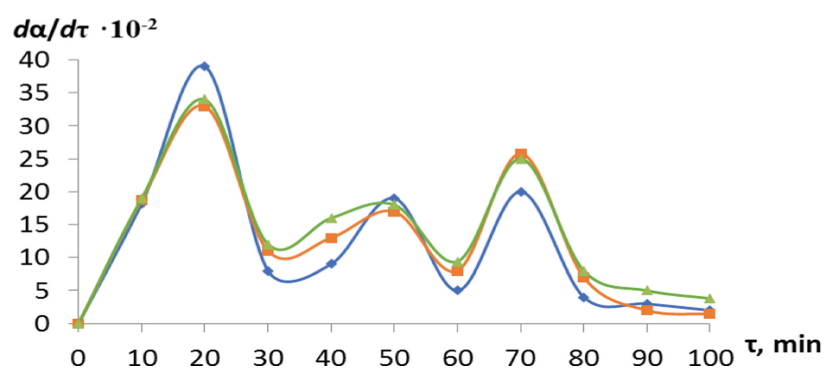

Fig. 2. Dependence of water loss on time at heating rates $10{ }^{\circ} \mathrm{C} / \mathrm{min}$ : — Portland cement; Portland cement with 5\% liquid glass; _ Portland cement with $10 \%$ liquid glass

Dehydration rate decrease during the first and the second climax for cement brick with 5 and $10 \%$ of liquid glass has a significant impact on micro cracking minimization in the surface layer of protective-decorative coating of composite finishing material at plasma-chemical modification. Dehydration intensification can result in microcracks increase and reduce to zero the positive influence of liquid glass in the coating. This effect takes place at adding $10 \%$ liquid glass into Portland cement. Thus, the received 
laws analysis of mass loss and dehydration rate of the studied compositions drew to a conclusion that the optimal is liquid glass component in the ratio $5 \%$ of mixing water.

\section{Conclusions}

The influence pattern character has been determined of liquid glass content on ettringite dehydration rate, calcium hydroxide and secondary carbonate, which is in endoeffects shift in low temperature area to lower temperatures, and in high temperature area to the area of high temperatures. This minimizes dehydration in low temperature area, cement brick softening and micro cracking and as a result provides adhesion strength improvement of protective-decorative coating with the concrete layer.

Acknowledgements. The work is realized with the financial support of the Grant of the President for scientific schools, No. NSh-2724.2018.8, using equipment of High Technology Center at BSTU named after V.G. Shukhov.

\section{References}

Bessmertny VS, Puchka OV, Bondarenko DO, Antropova IA, Bragina LL (2018) Plasmochemical modification of wall building materials. Constr Mater Prod 1(2):11-18

Bondarenko DO, Bondarenko NI, Bessmertnyi VS, Strokova VV (2018a) Plasma-chemical modification of concrete. Adv Eng Res 157:105-110

Bondarenko NI, Bessmertnyi VS, Borisov IN, Tymoshenko TI, Burshina NA (2016a) The concrete with protective and decorative coverings on the basis of alyuminatny cements which are melted off by the plasma stream. Bulletin of Belgorod State Technological University named after V.G. Shukhov, vol 2, pp 6-12

Bondarenko NI, Bondarenko DO, Burlakov NM, Bragina LL (2018b) Investigation of influence of plasmochemical modification on macro- and microstructure of surface layer of autoclave wall materials. Constr Mater Prod 1(2):4-10

Volokitin O, Volokitin G, Skripnikova N, Shekhovtsov V (2016) Plasma technology for creation of protective and decorative coatings for building materials. In: AIP conference proceedings, vol 1698, p 070022

Open Access This chapter is licensed under the terms of the Creative Commons Attribution 4.0 International License (http://creativecommons.org/licenses/by/4.0/), which permits use, sharing, adaptation, distribution and reproduction in any medium or format, as long as you give appropriate credit to the original author(s) and the source, provide a link to the Creative Commons license and indicate if changes were made.

The images or other third party material in this chapter are included in the chapter's Creative Commons license, unless indicated otherwise in a credit line to the material. If material is not included in the chapter's Creative Commons license and your intended use is not permitted by statutory regulation or exceeds the permitted use, you will need to obtain permission directly from the copyright holder.

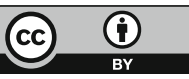

